\title{
THOMAS POTTS AND THE FOREST QUESTION: CONSERVATION AND DEVELOPMENT IN NEW ZEALAND IN THE $1860 \mathrm{~S}$
}

\section{Abstract}

Environmental historians need to differentiate between the origin of forest concerns on one hand, and the structuring of legislative responses on the other. The former began at the local level and resulted mostly in tree-planting in the first instance. The latter developed later, and drew not only on local realities, but also on American or European precedents. In New Zealand in the 1860s, concern for the native environment was primarily an aspect of concern for colonial development, and conservation of native forests was primarily a counterpoint to exotic tree-planting.

The advent of native forest conservation in the Colony has been traced back to a demand made in 1868 by Thomas Potts, that government consider 'the present condition of the forests'. This article closely examines the situation in the province where Potts lived, in the decade before the New Zealand Forests Act of 1874, to find out what sparked this kind of initiative. The American George Perkins Marsh's thinking, together with Australian legislative precedents, are confirmed as key external influences upon how concern about forests and conservation was framed, but in essence this concern was a local response to ongoing change in a local environment. What Potts and others expressed in the 1860s was grounded in what they themselves experienced: forest and fire, waste and shortage, development and opportunity.

By the 1870s, Potts doubted the effectiveness of legislative solutions and his response to timber shortage focused more on exotic tree-planting than on saving existing forest. This article affirms the importance, in a New Zealand context, of considering exotic plantation alongside native forest conservation. Turning to the broader picture, the evidence presented suggests that both local determinants and exotic tree-planting have been understudied by environmental historians, while aspects of conservation more readily associable with environmentalism and preservation may have been overstressed.

Keywords: conservation, tree-planting, colonial development, Thomas Potts, colonial New Zealand. 


\section{Introduction}

Something without precedent in New Zealand occurred in Parliament on 7 October 1868. Thomas Potts, the Member of the House of Representatives (MHR) for Mount Herbert in Canterbury, moved: 'That it is desirable Government should take steps to ascertain the present condition of the forests of the Colony, with a view to their better conservation'. ${ }^{1}$ This event is sometimes described as though it ushered in conservation in New Zealand, starting a chain of events which resulted in the protection of a considerable remnant of the natural environment. ${ }^{2}$ Clearly, however, Potts' motion did not just come into his head on that October day. This paper examines the influences before 1868 which worked upon him, and which were familiar enough to other MHRs for his motion on 'the present condition of the forests' to pass. Taking the examination a little further, to 1870, we can better assess whether Potts' outlook in the 1860s really reflected some kind of proto-environmentalism.

In recent decades, environmental historians (particularly in America) have unpicked the history of conservation. Along the way, the meanings of the words 'conservation', 'environmentalism', and 'natural', all used in the above paragraph, have been fiercely debated. Since the publication in 1995 of William Cronon's article on 'The Trouble with Wilderness' in a collection engaged in 'rethinking the human place in nature', we have even come to view nature as a human construct, and to consider natural environments only natural in so far as they are less unnatural than consciously built environments. ${ }^{3}$ In common with all of his generation of European-born pioneers, Potts did not think in these terms and under-appreciated the extent of changes that indigenous people (Māori, in this case) had effected on their surroundings. He still described the New Zealand 'environment' (a word whose meaning has become equally subject to rapid change) in terms of its natural history, as a 'slumbering wilderness', only awakening in the nineteenth century from 'the silent trance of ages' .

$1 \quad$ New Zealand Parliamentary Debates (NZPD) 7 October 1868: 188.

2 See, for instance, Simon Nathan, 'Conservation: A History: Voices in the Wilderness, 1769-1907', Te Ara: The Encyclopedia of New Zealand, updated 13 July 2012, www.TeAra.govt.nz/en/conservation-a-history/ page-3; David Young, Our Islands, Our Selves: A History of Conservation in New Zealand (Dunedin: University of Otago Press, 2004), 72-77.

3 William Cronon, 'The Trouble with Wilderness, or, Getting Back to the Wrong Nature', Uncommon Ground: Rethinking the Human Place in Nature (New York: W.W. Norton, 1995), 69-90.

4 T. H. Potts, 'Out in the Open: A Budget of Scraps of Natural History', New Zealand Country Journal 2 (1878): 139. For the actual extent of pre-European Maori impact, see Atholl Anderson, 'A Fragile Plenty: Pre-European Maori and the New Zealand Environment', in Making a New Land: Environmental Histories of New Zealand, new ed., ed. Eric Pawson and Tom Brooking (Dunedin: Otago University Press, 2013), 35-51. 
In 1989, Roderick Nash underlined 'the qualitative difference between "environmentalism", as it emerged in the 1960s, and what used to be called "conservation"". ${ }^{5}$ He saw the new 'environmentalism' as an ethical approach to nature, while the old 'conservation', as it was understood by the American forester Gifford Pinchot in the 1900s (and by Potts in the 1860s), had demonstrated an economic approach. If this insight is accepted, the difficulties inherent in identifying nineteenth-century conservationists as proto-environmentalists become more apparent, since it implies that these pioneers beat two very different tunes at the same time. Yet, as an examination of Potts' motives will suggest, an early conservationist would not have viewed ethical and economic approaches to the natural environment as two opposing poles. Nineteenthcentury conservation aimed to reduce waste by being 'economical' in the use of natural resources, and this was, arguably, profoundly ethical.

In the context of New Zealand environmental history at least, an attempt has been made to distinguish between 'conservation', which encourages 'wise use' or 'sustainable management' of protected indigenous ecosystems, and 'preservation', which implies their immunity from any direct utilisation, whether felling individual trees or harvesting limited numbers of native birds or animals. ${ }^{6}$ In New Zealand after the early 1870 s - that is, beyond where this study ends - the idea of conservation was increasingly overlaid with glimmers of this concept of preservation. Potts was in the vanguard in this respect, but he has further significance because we have good evidence of how his attitude to forests changed. Over a period of 34 years (1854-88) we are able to plot, through his example, the origin and development of a preservationist approach. This article provides a fresh look at what sparked that process, and at part of the picture - exotic tree-planting - which has been under-studied since the emphasis has been on those aspects of conservation more readily associable with environmentalism and preservation.

New Zealand's forest history was first examined in this light in an article published by the Canadian historical geographer Graeme Wynn in 1977, which focused on the parliamentary debate in 1874 on Premier Julius Vogel's New Zealand Forests Bill. According to Wynn, supporters of the bill 'accepted the evidence of man's deleterious impact on nature in America and Europe' and Vogel's perspective 'recognised the ecological and long-term benefits of conservation'. Wynn devoted only one paragraph to the debate on New Zealand's forests

5 Roderick Frazier Nash, The Rights of Nature: A History of Environmental Ethics (Madison: University of Wisconsin Press, 1989), 8.

6 Paul Star, 'Native Forest and the Rise of Preservation in New Zealand (1903-1913)', Environment and History 8, no. 3 (August 2002): 276. This differentiation also has its difficulties, not least because the two words are often treated as synonymous: for instance, since 1987 responsibility for the preservation of New Zealand's indigenous ecosystems has rested with what is called the Department of Conservation. 
before 1874, prompted by 'the urgings of a handful of settlers', including Potts, and concluded that this 'was more effective in revealing the limited sympathy for restraint and resource conservation in this pioneering society than it was in achieving action to temper ecological disturbance' ${ }^{7}$

There are various points to raise about the kind of analysis initiated by Wynn. Firstly, it was clearly not enough to deal with precedents for Vogel's bill in a mere sentence or two - another historical geographer, Michael Roche, duly provided much more of this background. ${ }^{8}$ Secondly, New Zealand's forest history needed firmer placing within an international context - and work by James Beattie and other environmental historians has since started to fill this gap. ${ }^{9}$ Thirdly, to consider opinions and forestry legislation from this period in such ecological terms seems a problematic, and potentially misleading, approach, given that the very term 'oecologie' (or oecology or ecology) was only coined in German in 1866, did not appear in English until 1875, and is first found in a New Zealand publication in $1899 .{ }^{10}$

Wynn stated that the American 'George Perkins Marsh's recently published and prescient evaluation of man's destructive impact on his environment ${ }^{\prime 11}$ influenced Potts and a few New Zealand settlers in the late 1860s, which is certainly true, but what needs to be established is the place that this study, and other overseas influences, occupied in the creation of a New Zealand approach to forest conservation. It is with this in mind that the present paper looks at a much fuller range of influences that were at work upon Potts during the 1860s, several years before Vogel, most notably, turned his attention to the matter. While the significance of Marsh and of Australian precedents is confirmed, greater stress is given to the local context. This paper affirms the importance of considering together exotic tree plantations and native forest, the drive to develop and concern for the environment.

\footnotetext{
7 Graeme Wynn, 'Conservation and Society in Late Nineteenth-Century New Zealand', New Zealand Journal of History 11, no. 2 (1977): 136, 133 and 125.

8 Michael Roche, Forest Policy in New Zealand: An Historical Geography, 1840-1919 (Palmerston North: Dunmore Press, 1987); Michael Roche, History of New Zealand Forestry (Wellington: GP Books, 1990).

9 James Beattie and Paul Star, 'Global Networks and Local Environments: Forest Conservation in New Zealand, 1850s-1920s', British Scholar 3, nos. 1-2 (September 2010): 191-218; James Beattie, Empire and Environmental Anxiety: Health, Science, Art and Conservation in South Asia and Australasia, 1800-1920 (Basingstoke: Palgrave Macmillan, 2011).

10 Leonard Cockayne, 'A Sketch of the Plant Geography of the Waimakariri River Basin, Considered Chiefly from an Oecological Point of View', Transactions of the New Zealand Institute 32 (1899): 95-136.

11 Wynn, 'Conservation and Society', 125.
} 
There was no typical New Zealand province: Canterbury, where Potts lived, was in fact unusual in having so limited a forest resource. While Otago was also short of timber, in most other places it was abundant. ${ }^{12}$ Nor was Potts typical of his generation, although he did respond to events that other early European settlers also experienced. His importance lies in the unusual amount of thought he gave to the environmental context of settlement, with much of what he wrote and said, in addition to records of what he did, surviving. It is, therefore, rewarding to try to see things through his eyes. From this launching point, we can consider more generally what other European settlers in New Zealand made of, and wished to make of, their new country.

Thomas Henry Potts - to give a few biographical details - was born in London in 1824 and as a young man lived on his country estate near Croydon in Surrey, with its 100 acres (40 hectares) of fields and woodland. At the age of 30 he sold the estate and the family's gun-making business and sailed for Canterbury, New Zealand. Here he established Hakatere, a cattle and sheep station by the upper Rangitata River, which at its peak covered 81,000 acres (33,000 hectares). Others managed Hakatere for him, while he, his wife, and their 13 children resided within easier reach of Christchurch: near Lyttelton, on a freehold property of about 600 acres (250 hectares). From this base, Potts served both on the Canterbury Provincial Council and (as already mentioned) in New Zealand's House of Representatives. Increasingly, however, his home, his family, and his garden, along with his natural history interests and his writing, took centre stage. By the time of his death, in 1888, he had written close to 100 articles and one book, Out in the Open (1882), which was the first substantial volume of natural history published in New Zealand. ${ }^{13}$

\section{Canterbury's development}

When Canterbury Association settlers, such as Potts, approached their destination in the 1850s, their first views were of a landscape distinctly different from most of the area they were to settle. To the east of the entrance to Lyttelton Harbour were the mouths of Port Levy and Pigeon Bay, with the hills of Banks Peninsula rising steeply above them. These parts of the Peninsula were hilly and heavily forested. They promised an extensive supply of timber, but limited flattish land suitable for arable farming. In contrast, the vastly larger expanse

12 Canterbury and Otago provinces, as first defined, included extensive forests on the western side of the South Island. However, this timber resource was not readily accessible from the eastern side where most human settlement occurred, and beyond which Canterbury and Otago's boundaries did not extend once Westland gained full provincial status in 1873.

13 For a photograph of Potts, and further biographical details, see Paul Star, 'Tree Planting in Canterbury, New Zealand, 1850-1910', Environment and History 14, no. 4 (November 2008): 563-82. 
of the Canterbury Plains was mostly flat and without trees. The early years of the Canterbury settlement saw no lack of land convertible to agriculture, but there were soon problems in sourcing sufficient timber for the province's development.

Having sailed into the harbour and to the port of Lyttelton - which, given the nature of the steep terrain immediately behind it, could never become a large town - the settlers hastened to climb the Port Hills to view the land beyond. This strenuous walk was no doubt undertaken by Henry Phillips (Potts' fatherin-law) soon after he arrived in Lyttelton with his family, on one of the first four ships sent out by the Canterbury Association, in December 1850. The same ground would have been covered, using the Bridle Path, by Potts when he arrived with his wife and their first three children, in 1854. Potts recalled in 1887 that,

[t]he summit attained, with a very short walk an excellent view of the great plain was obtained, the universal brown tussock chequered here and there with large dark patches, the woods of magnificent trees which now have been swept away these many years. ${ }^{14}$

By 1854 Lyttelton had a population of about 800. Christchurch had fewer people - about 600-but geography determined that the future of the colony depended upon the expansion of this 'rather dreary little village', described by one historian as looking then 'more like an offshoot of the Wild West than of the home counties' ${ }^{15}$ As the population increased and more settlers moved out to Christchurch and its hinterland, it became imperative to somehow improve the flow of people and goods between Christchurch and the port at Lyttelton.

The solution was to build a railway and tunnel through the Port Hills. This was risky, since it depended on the latest geological knowledge and engineering expertise, and financially on a high level of debt. The initial decision to proceed was made by the members (MPCs) of the second Canterbury Provincial Council when they passed the Railway Bill in April 1860. This approved a proposal initiated and subsequently masterminded by the head of Canterbury's government: the superintendent, William Sefton Moorhouse. ${ }^{16}$

By this time Potts was well known. As a large runholder, he could afford to serve as an MPC in Christchurch along with 25 other gentlemen, and he was a supporter of the tunnel project. ${ }^{17} \mathrm{He}$ had reason to be, since many of his

14 'Old Times', Canterbury Times, 18 November 1887, 25.

15 G. C. Hensley in A History of Canterbury, vol. 2, General History, 1854-76, and Cultural Aspects, 18501950, ed. W. J. Gardner (Christchurch: Whitcombe and Tombs, 1971), 5.

16 See W. H. Scotter, 'Moorhouse and the Tunnel Contract, 1857-63', in A History of Canterbury, vol. 2, ed. Gardner, 77-104.

17 Lyttelton Times, 25 April 1860. 
interests, like those of his constituents in Port Victoria (Lyttelton Harbour), required a journey from the Lyttelton side of the Port Hills to Christchurch. Since early in 1858 he and his large family had lived in Governor's Bay, on the shores of Lyttelton Harbour, in a substantial house and property bought from his friend and mentor, Moorhouse. ${ }^{18}$

As an MPC, Potts was one of those who, in May 1861, approved Moorhouse's choice of a Melbourne firm to take over the contract to construct the Lyttelton to Christchurch railway, including the tunnel. The previous contract had turned sour when the first firm involved sought to raise their price, but the new contract, with Holmes and Co., still committed Canterbury to borrowing $£ 240,500 .{ }^{19}$ Since the future of the colony depended on the venture's success, once the new contract was signed there was a very strong incentive to shield Holmes and Co. against any impediment to their completion of the task.

Once the Provincial Superintendent turned the first sod, work started on the railway and tunnel in July. ${ }^{20}$ Fifteen months later, his wife Jane was at the Heathcote (the northern or Christchurch) end of the tunnel for a further ceremony, laying the first stone of the tunnel arch. ${ }^{21}$ By then, Holmes' navvies had removed rock from as far as 400 yards (365 metres) into the Port Hills on both sides, but a further 2,038 yards (1,864 metres) still needed boring. The tunnel was not completed until five years later, in 1867. In 1862, the brickwork had just been started, using bricks 'burnt in the valley and at Pigeon Bay' on Banks Peninsula. Pigeon Bay was also the anticipated source of timber for the project, including railway sleepers.

Potts sailed from Lyttelton for England in March 1862 and did not return until January $1863,{ }^{22}$ so he missed the Heathcote ceremony. He needed to tie up the loose ends of his financial affairs, but at least one attraction also drew Potts back to England at this time. He had been deeply impressed by the Great Exhibition of 1851; he was now able to visit London's International Exhibition, which ran from May to November 1862.

The 1862 exhibition included a New Zealand Court, in which merino wool from Canterbury featured prominently. By this time wool had become the province's 'staple article of production and exportation' ${ }^{23}$ Perhaps the exhibits which most struck Potts, however, were 'some splendid articles of furniture made of kauri

18 T. H. Potts, Diary, 20 February 1858.

19 Lyttelton Times, 18 May 1861.

20 Lyttelton Times, 20 July 1861.

21 Lyttelton Times, 1 October 1862.

22 Lyttelton Times, 8 March 1862 and 10 January 1863.

23 Lyttelton Times, 8 February 1862. 
wood sent from Auckland', which were 'very highly valued indeed' ${ }^{24}$ Nelson province, more immediately north of Canterbury, also displayed 'samples of furniture made from native woods, the very names of which would make the fortune of advertising upholsterers. Red manuka chairs, totara couches, and titree tables ... ought really to create a new sensation' ${ }^{25}$

Canterbury province possessed no kauri (Agathis australis), but there were workable and durable woods among the podocarp species, such as totara (Podocarpus totara), so well established on Banks Peninsula. Decades later, Potts was still reflecting on the 'specimens of carving which ... enriched and ornamented the New Zealand Court' and lamenting the wood-carving industry centred on a school of design which 'might have been [but never was] the fate of such an eligible spot as Akaroa', the Peninsula's largest settlement. ${ }^{26}$

\section{The fires of 1863}

After attending the exhibition, Potts returned from England on 7 January 1863 with an enhanced appreciation of the value of the Peninsula's forests, visible from his windows. Ten days later, young James Hay was having problems moving his father's cattle away from scrub on their property in Pigeon Bay. To drive them out, he set fire to the 'wild Maori grass', which was 'as high as the knees and just as dry as powder'. Things got out of control, and the fire spread into the forest on adjoining properties and thence across much of Banks Peninsula, where it continued to burn for months. In particular, fire had reached the edge of George Holmes' Craigforth estate, a mile away, by early February and burnt through a great deal of his bush. Some of the totara trees destroyed were 'six feet thick'. By the time fire got down to Holmes' house, on 12 February, an estimated 500 acres (200 hectares) had been burnt over, containing about six million feet of timber. ${ }^{27}$

In a Supreme Court hearing in August 1863, Holmes sought damages from Ebenezer Hay (as the father of James) for the loss of his timber. Holmes' lawyer, William Travers, ably represented that the fire on his client's land had resulted from James Hay's actions, rather than from any other fires started in the same period. Witnesses for the defence spoke of fires in the Mount Fitzgerald, Port Levy, and Little River areas at the time, for it was common practice to

\footnotetext{
24 T. H. Potts, 7 October 1868, NZPD 14 (1868): 188.

25 Lyttelton Times, 7 May 1862.

26 T. H. Potts, 'Out in the Open', New Zealand Country Journal 10, no. 2 (1 March 1886): 89.

27 Lyttelton Times, 22 September 1863. Timber measurements are notoriously difficult to deal with. It is unclear here whether the speaker (George Marshall) meant six million super (board) feet (14,160 cubic metres) or six million running (lineal or linear) feet $(2,044,800$ metres).
} 
carry out clearances or to induce nutritious new growth of grass by means of burn-offs. Since farmers saw their future in terms of pasture rather than native forest, the chance of a burn-off becoming a bush fire was not the most important consideration. Never before, however, had the settlers on Banks Peninsula witnessed fires as extensive as those of 1863. The jury decided for the plaintiff, and Mr. Justice Gresson ordered Ebenezer Hay to pay Holmes £3,000 in damages. ${ }^{28}$

This was no ordinary court case. Its significance lay in the magnitude of the damages awarded and the nature of the property that had been damaged: these were points made when the case was recalled in Parliament in 1868. Furthermore, the people involved were significant. The Hay family had been in Canterbury for 20 years, as part of the small influx of Scots who arrived in advance of the major Canterbury Association settlement of 1850. Ebenezer Hay and Captain Sinclair had brought William Deans to Canterbury in their boat in February 1843, then their own families three months later.

While the Deans chose to live at Riccarton Bush on the plains, the Sinclairs and Hays settled on the forested slopes of Pigeon Bay. In 1850, much of the timber to build the new town of Lyttelton, including the totara piles for the jetty, was sourced from the Hays' property in Pigeon Bay. ${ }^{29}$ Although the Hays as a family returned to prosperity after 1863 (and still farm in the Bay today), Gresson's ruling broke their patriarch. The sum of $£ 3,000$ was a very large one to lose. Hay unsuccessfully appealed against the judgement in October $1863 .{ }^{30}$ In November, returning to Lyttelton over the Bridle Path after visiting his solicitor in Christchurch, he fell down a bluff to his death. ${ }^{31}$

Shortly before the fires, the Hay's neighbours, the Sinclairs, had sold out to George Holmes and moved to Vancouver. The Lyttelton Times, reporting this on 29 October 1862, recognised its significance at once:

[t] he inhabitants of Banks Peninsula may be congratulated upon the purchase of the estate of Craigforth in Pigeon Bay by Messrs Holmes and Co, the contractors for the tunnel and railway, who are about to immediately establish two powerful saw mills in the forest, which covers a very large area of land of many hundreds of acres ... [this is] a fresh guarantee of the bona fide intentions of the railway contractors to complete the great undertaking they have in hand[.. ${ }^{32}$

28 Lyttelton Times, 26 September 1863.

29 Gordon Ogilvie, Banks Peninsula: Cradle of Canterbury, 3rd ed. (Christchurch: Phillips and King, 2007), 85-98.

$30 \quad$ Lyttelton Times, 8 October 1863.

31 Lyttelton Times, 5 December 1863.

32 Lyttelton Times, 29 October 1862. 
The destruction, three months later, of a sizeable proportion of the timber Holmes had intended to mill - both directly for use on the railway, and indirectly to sell to others to help his cash flow-was not just a blow to him; it must also have threatened to stall, for a second time, the building of the Lyttelton to Christchurch railway and tunnel. The decision to award substantial damages to Holmes ensured that the project was not delayed by any unexpected dip in Holmes' capital.

But it was not just money that was scarce and had been lost; it was also, irretrievably, timber. Yet enough remained on Holmes' land for the main project in hand, since by 1868 'the thirty miles [48.3 km] of railway already constructed in Canterbury was derived from that single forest'. This was stated by Holmes' lawyer, Travers, who, like Potts, became a proponent of native forest conservation. ${ }^{33}$

Unlike Travers, Potts appears to have had no direct involvement in the case of Holmes v. Hay, though as one of the MPCs who had authorised the railway contract with Holmes and Co he must have been particularly anxious for the success of Holmes' venture. A year later, Potts was a member of the special jury of 12 at the Supreme Court hearing, again heard by Gresson, which considered the case of Marshall v. (James) Hay. George Marshall was another landowner in Pigeon Bay whose forests were destroyed in the 1863 fires, and a similar range of evidence was presented to that in the Holmes case. This time, however, the jury was not convinced that the damage to Marshall's forest could be clearly linked to the fire originally lit by James Hay, so Marshall received no recompense. ${ }^{34}$ One can only wonder if the jurors felt that the Hays had been punished enough already, or perhaps that Marshall's solvency was less important than Holmes'.

For Potts, the whole sequence of events had a significance which only grew with time. He, like Travers, referred in 1868 to the Pigeon Bay fire as one of 'a most destructive character', adding that 'he had often seen Banks' Peninsula covered for weeks together, with thick and lurid smoke'.$^{35}$ The evidence of a tragic waste was there before his eyes, but it was less clear how it could be prevented.

33 W. T. L. Travers, 7 October 1868, NZPD 14 (1868): 191

34 The Press, 20 September 1863; Lyttelton Times, 21 September 1863.

35 T. H. Potts, 7 October 1868, NZPD 14 (1868): 189. 


\section{Approaches to timber shortage}

Given the continuing and accelerating need for timber in Canterbury, together with the rapid depletion of the province's remaining native forest, a worrying situation lay ahead. Settlers alert to it envisioned three quite distinct ways in which the problem of a timber shortage could be alleviated.

Firstly, timber might be imported from elsewhere, but this was a costly solution for a young colony short of ready cash. It was a makeshift approach, already relied upon for a large proportion of Canterbury's needs. Potts would have been well aware of both the demand for and supply of timber imported from other provinces or other countries. Montgomery, Todhunter and Co., for instance, imported 29,000 feet (68.44 cubic metres) of timber from Wellington, which arrived at the Heathcote River on 12 January 1863, just before Pigeon Bay began to burn. The firm sold not only totara from elsewhere in New Zealand and kauri from Auckland, but also American shelving and Tasmanian palings. ${ }^{36}$ In all, between 5 and 19 January, 61,500 feet (145.14 cubic metres) of timber from Banks Peninsula (shipped from Akaroa) reached Christchurch, while 102,000 feet (250.72 cubic metres) was shipped from Wellington to the same destination. ${ }^{37}$

As a second approach to the shortage, more trees could be planted, which might have provided a solution if only they had grown fast enough. I discuss this later. Thirdly, it might have been possible to have exercised greater control over the exploitation of native forests. This would have ensured not only a less wasteful consumption of those trees removed, but also conservation of some areas, so that at least some native timber would have remained available in the long term. Conservation, in the nineteenth-century usage of the word, implied a measured and (arguably) rational utilisation of forests, but not their complete preservation against every kind of exploitation. It is for his early promotion of the conservation of New Zealand's forests, together with his later steps towards more recent ideas of preservation, that Potts is most remembered.

\section{Native forest conservation in Canterbury before 1868}

Ever since his arrival in Canterbury, the wastage of the forest resource had upset Potts. He was not alone in this. Indeed, his father-in-law condemned it at a Colonists' Committee meeting in January 1851, just three weeks after his arrival

\footnotetext{
36 The Press, 21 June 1862.

37 Lyttelton Times, 21 January 1863. These figures do not include 2,090 'pieces' of timber, and 2,000 palings arriving at the Heathcote River from Picton on 19 January.
} 
in New Zealand, when he addressed the subject of indiscriminate licences granted by the [Canterbury] Association for cutting timber and complained that the purchasers of land were injuriously affected by it' ${ }^{38}$ In 1856 , Potts had watched with some concern as men took timber and firewood near Phillips's Rockwood Station at Hororata, about 50 miles (30 kilometres) west of Christchurch. He thought it would 'destroy much of the ornamental character of Rockwood, not so much on account of the gap left by the trees they throw, as by the effect of these gaps on the bush remaining' ${ }^{39}$

An article in the Lyttelton Times in 1857 also protested against licensed timbergetting on reserved land, which caused 'great ... injury to public property' ${ }^{40}$ Due to the difficulty of enforcing timber licensing regulations, none were in fact issued for Banks Peninsula from the mid-1850s until 1864, control being attempted instead through the creation of 'timber reserves' or 'bush reserves' on Crown land, adjacent to existing sawmills, where the exploitation (and ultimately the exhaustion) of the resource could in theory be monitored. Timber licensing again became available from 1864, and again proved unsatisfactory, leading to its abandonment as a management technique throughout Canterbury in $1870 .{ }^{41}$

Many years later, Potts recalled his dismay at the wasteful utilisation of the 'magnificent timber on the Port Hills' that he had witnessed. He often found totara stripped of its bark for use as 'the roofing of a wretched hut', causing the ruination of the tree itself. It was, he said, a wish

to point out the mischief occasioned by this destructive usage that led [me] to a fruitless interview with a Provincial Secretary [John Ollivier] some thirty years ago. It took but a few minutes to discover the unprofitableness of this proceeding; with the utmost urbanity of demeanour, the worthy official showed that he neither knew nor cared a rapp about the matter. The expensive system of timber-cutting without efficient supervision, remained unchecked. ${ }^{42}$

This was written in 1887, indicating that Potts first actively (but unsuccessfully) sought more effective forest conservation in the late 1850 s.

As the bush fires of 1863 burnt their way across Banks Peninsula's forests, the question of how to conserve the remaining forest gained greater urgency for Potts. He was not, however, an MPC at the time, so did not participate in the Council session which opened in September 1863. This was just a few days

38 Henry Phillips in Minutes Book, Society of Canterbury Colonists, 1850-52, Christchurch Public Library, z Arch 16 (n. p.).

39 T. H. Potts, Diary, 25 July 1856.

40 Lyttelton Times, 25 February 1857.

41 For further details of timber legislation in Canterbury during this period, see Roche, History of New Zealand Forestry, 74-83.

42 T. H. Potts, 'Old Times', Canterbury Times, 2 December 1887, 28. 
before the case of Marshall v. Hay was heard in the Supreme Court, when every member knew that 'a great quantity of timber ... had been injured by the late fires' ${ }^{43}$ Getting straight down to business, the Council discussed a Bush Fires Bill (passed the following day) which 'provided that any person setting fire to any grass, fern, scrub, etc, should be fined not less than forty shillings', a provision which Ollivier denounced as 'unnecessary'. ${ }^{44}$

Potts resumed his duties as an MPC in 1866, continuing to serve until the abolition of the provincial governments in 1876, but there is nothing to suggest that he brought his concern about forests to the Council's attention in the late sixties. From 1866 to 1870 , however, he was also regularly in Wellington as MHR for Mount Herbert (Banks Peninsula), which enabled him to raise the issue at the national level in 1868. If forest conservation was necessary and could be achieved through legislation, this was the more important audience to convince.

In 1860s Britain, there was a burgeoning concern with the supply of resources needed to fuel and support the nation's industrialisation and development. This at least equalled a parallel anxiety about the effect of such rapidly expanding extraction and production upon the environment in which people lived. ${ }^{45}$ For Britain's ongoing industrial revolution, the supply of coal appeared crucial, and in 1865, for the first time, its long-term availability was brought into question. ${ }^{46}$ In that year, the English economist William Stanley Jevons published his influential enquiry 'concerning the progress of the nation and the probable exhaustion of our coal-mines' ${ }^{47}$

Jevons' arguments were detailed in the Christchurch newspaper, The Press, in April 1866. Potts (though not Travers) was in the House of Representatives in Wellington by October 1866 when the Premier, Edward Stafford, recorded the completion of geologist James Hector's 'report on the Coal Fields of the Colony for the Imperial Government, who wished for information on Colonial Coal Fields, in consequence of Mr Jevons' observations on the exhaustion of the coal fields of England'. It is plausible that British anxieties about coal helped both

\footnotetext{
43 J. G. Fyfe, MHR for Port Victoria, reported in Lyttelton Times, 16 September, 1863.

44 The Press, 16 September 1863.

45 Beattie, Empire and Environmental Anxiety, 11, briefly summarises the 'origins of environmental anxiety', while James Winter, Secure from Rash Assault: Sustaining the Victorian Environment (Berkeley: University of California Press, 1999) provides details of the British response.

46 See Andreas Malm, 'Fleeing the Flowing Commons: Robert Thom, Water Reservoir Schemes, and the Shift to Steam Power in Early Nineteenth-Century Britain', Environmental History 19 (2014): 55-77, on why coal became crucial to Britain's industrial development. Nuno Luis Madureira, in 'The Anxiety of Abundance: William Stanley Jevons and Coal Scarcity in the Nineteenth Century', Environment and History 18 (2012): 395-421, claims (page 421) that '[c]ore themes in ecological thinking, such as the exhaustion of natural resources, the rebound effect and the limits to economic growth, came out into the open through discussion of the coal question'.

47 W. S. Jevons, The Coal Question: An Enquiry Concerning the Progress of the Nation and the Probable Exhaustion of our Coal-Mines (London: Macmillan, 1865).
} 
Hector and Potts towards more careful consideration of the future supply of New Zealand's principal fuel source (as well as its main construction material): that is, of wood. ${ }^{48}$ It is much more evident, however, that the views of American and Australian thinkers exerted a strong influence, since they applied specifically to timber and to the situation faced by similar pioneering communities.

\section{The influence of G. P. Marsh}

More than five years after they had witnessed the bush fires of 1863 on Banks Peninsula, Potts and Travers (both MHRs in 1868) referred to them while debating 'the forests of the colony'. Introducing his motion on the 'present condition' of forests, Potts said he 'had waited with patience to see if some steps would be taken to preserve the forests which were the admiration of every visitor to New Zealand; and he considered it was quite time that some action should be taken in the matter' ${ }^{49}$

From the years between 1863 and 1868, two factors stand out which, I believe, crystallised his thoughts and prompted him to call for action. He mentioned both in his speech in 1868. The first was his study of material presented in Man and Nature by George Perkins Marsh, though precisely when Potts read this book I do not know. The second was his knowledge of forest legislation in the Australian colony of Victoria. Taken together, these factors placed what was happening to Canterbury's forests within an international and an intellectual context which Potts had previously seen but dimly.

In his 1868 speech, Potts also quoted two early scientific visitors to New Zealand: Ernst Dieffenbach, an 'official of the New Zealand Company' who was in the North Island from 1839 to 1841, and geologist Ferdinand von Hochstetter, in the north and in Nelson province between 1857 and $1859 .{ }^{50}$ Like Potts, these men had seen forests 'ransacked and ravaged with fire and sword' in which 'a melancholy scene of waste and destruction presented itself', but neither got much further than their expressions of alarm.

\footnotetext{
48 'The Duration of our Supply of Coal', The Press, 18 April 1866, 2; Wellington Independent, 4 October 1866, 5. I know of no explicit juxtaposition of Britain's coal demands and New Zealand's timber demands prior to an optimistic piece about 'Using Up the World's Products' in the Bruce Herald, 10 September 1886, 5.

49 T. H. Potts, 7 October 1868, NZPD (1868): 188.

50 James Braund analysed the origins of Hochstetters's interest in forest conservation in 'The Geologist and the Ravaged Kauri Forest: Ferdinand von Hochstetter as an Environmental Commentator' (paper presented at the New Zealand Historical Association Conference, University of Otago, Dunedin, 20 November 2013). See also James Braund, ed., Ferdinand Hochstetter and the Contribution of German-Speaking Scientists to New Zealand Natural History in the Nineteenth Century (Frankfurt: Peter Lang, 2012).
} 
Marsh went well beyond this. He had spent much of his first 60 years in Vermont, during which time the state's forest cover was reduced from three-quarters to one quarter of its original area. Marsh was a lawyer and politician, but also a sheep farmer and timber dealer, so 'had occasion both to observe and to feel the evils resulting from an injudicious system of managing woodlands'.$^{51}$ There are clearly parallels between Marsh's experience in Vermont and Potts' experience in Canterbury a generation later.

When, aged 60, Marsh moved to Italy, he combined his duties as American ambassador with wide-ranging scholastic pursuits. This enabled him to place the environmental degradation of Vermont alongside examples of similar events in classical times and in modern Europe. In turn, this resulted in the insights that appeared in Man and Nature.

David Lowenthal has called this work 'one of the nineteenth century's two seminal books on the subject its title denoted', the other being Charles Darwin's On the Origin of Species (1859). Man and Nature was published in New York in May 1864, and over 1,000 copies sold in a few months. ${ }^{52}$ It received a lengthy review in an Australian newspaper, the Sydney Empire, in August 1864. ${ }^{53}$ Shorter notices in the Nelson Examiner in September and the New Zealand Herald in November ${ }^{54}$ did little more than quote Marsh's stated intention:

to indicate the character and, approximately, the extent of the changes produced by human action in the physical condition of the globe we inhabit; to point out the dangers of imprudence, and the necessity of caution in all operations which, on a large scale, interfere with the spontaneous arrangement of the organic or the inorganic world; to suggest the possibility or importance of the restoration of disturbed harmonies, and the material improvement of waste and exhausted regions $[.]^{55}$

These ideas evidently took some time to digest. I have found no further mention of Man and Nature in Australian newspapers until June 1866, when the Brisbane Courier reprinted an article from the New York Post on 'the effect of stripping a country of trees'.$^{56}$ A second New Zealand review appeared in the Otago Daily Times in April 1866, but said nothing about conservation and mirrored none of Marsh's concern about 'the dangers of imprudence'. Rather, the reviewer found occasion to display a kind of colonial mindset that was fairly standard in the 1860s:

\footnotetext{
51 David Lowenthal, George Perkins Marsh: Prophet of Conservation (Seattle: University of Washington Press, 2000), 273.

52 Lowenthal, George Perkins Marsh, 305, 302.

53 The Empire, 25 August 1864.

54 Nelson Examiner, 6 September 1864; New Zealand Herald, 7 November 1864.

55 Marsh, Man and Nature, iii.

56 Brisbane Courier, 15 June 1866. This article then also surfaced in three other Australian papers.
} 
[t]he country is to make [that is, to be made] - the growth of centuries has to be cleared and supplanted by vegetation of another kind. In place of the primeval forest, fields of corn are to be raised. In lieu of ferns and mosses, pastures are to be prepared ... Such is the mission of colonists ... The earth has to be subdued, and rendered subservient to human will ... The tangled bush must then give place to the hedge-row and the road, and to plants and animals producing material for food or manufacture..$^{57}$

Both Marsh and Potts would have subscribed to this vision up to a point, and, indeed, they both pursued it. It was the consequences of its pursuit, when untempered, that troubled them.

Man and Nature, by collating evidence from throughout the world of the environmental effects of deforestation, painted a broad canvas within which local observers, such as Potts in Canterbury, could place their own experiences and better understand them. By providing such strong evidence that increases in instances of flooding and drought were often the consequence of forest clearance, Marsh supplied lobbyists with a further reason, above and beyond the prospect of timber shortages, for a more measured and restrained approach to the exploitation of remaining forests.

In his 1868 speech, Potts made specific reference to Marsh's evidence from the French Alps, which demonstrated the varied influence of the forests, as shelter, on temperature, on humidity, on floods, on the flow of springs; and his arrangement of facts proves the removal of forests to be the primary cause of excessive inundations'. Turning then to his local knowledge, Potts surmised a similar cause for changes to water flow in the Hutt Valley near Wellington, and he anticipated a similar scenario with forest destruction in Westland.

Later in the debate, Travers, another early reader of Man and Nature, described floods that followed disforestation in the Rhône Valley in France, then opined that 'the floods of the Waimakariri and other rivers had been enormously increased by the indiscriminate burning of the timber at the head of those streams' ${ }^{58}$ He also made detailed reference to Marsh's writings in his muchquoted first lecture 'on the changes effected on the natural features of a country by the sudden introduction of civilised races', delivered in Wellington a year later in August 1869. ${ }^{59}$

\footnotetext{
57 Otago Daily Times, 6 April 1866.

58 W. T. L. Travers, 7 October 1868, NZPD 14 (1868): 191. In terms of a more general 'environmental anxiety', Canterbury residents had plenty to worry about in 1868. A strong 'earthquake wave' was experienced at Lyttelton in August. The Waimakariri River, which had burst its banks and caused severe flooding in Christchurch in December 1865, again caused 'disastrous floods' in March 1868. Attempted solutions centred on earth moving, though tree-planting along the embankments was considered helpful. Lyttelton Times, 17 August, 4 March, and 10 January 1868.

59 Wellington Independent, 10 August 1869. Potts was in Wellington at the time, so was probably in the audience.
} 


\section{Forest conservation in Victoria and Otago}

Charles O'Neill, MHR for the Otago gold-fields, who also supported Potts' motion in 1868, may or may not have read Marsh by then, but he had certainly read the report of the board appointed in August 1867 in Victoria (Australia), 'to report on the best means of securing the permanency of the State forests of that Colony'. The examples $\mathrm{O}^{\prime}$ Neill quoted from the Victorian report had all been described beforehand in Man and Nature: the effects of forest destruction in the French Alps, but also in Spain, Palestine, and North Africa, and the 'aridity ... subdued through tree-planting in the Lands [near Bordeaux] and in Algeria' ${ }^{60}$

In the House of Representatives at least, Potts was never verbose. In contrast to O'Neill's lengthy quotations from the Victorian report, Potts merely stated that: 'The mischievous results from the cutting down of forests in a wholesale manner [have] called for the attention of the Legislature of Victoria'. ${ }^{61}$ It is, however, clear from his letters to the Lyttelton Times in January and February 1869 that Potts studied this document with care and was much influenced by it. $^{62}$

Victoria's chief mining surveyor and its Secretary for Mines were both on the board of five, which completed its report in February 1868. It was designed, in part, to address 'the necessity for permanent provision for a continuous supply of timber for mining purposes'. It is quite understandable that $\mathrm{O}^{\prime} \mathrm{Neill}$, who represented the largely treeless Otago gold-fields district in New Zealand's House of Representatives, had a copy of the report forwarded to him by Victoria's Minister of Mines. ${ }^{63}$ The roads to conservation taken by $\mathrm{O}^{\prime} \mathrm{Neill}$ (at first mostly concerned about the shortage of timber props for mining operations) and by Potts (who saw the 1865 West Coast gold rush as an unwelcome distraction from the serious business of colonisation) were quite different, but their destination was the same.

The Melbourne Argus, in welcoming the Victorian report, commented that

[e]xtensive as our forests still are, they cannot last long unless effectual regulations for preserving them in certain districts be established. Discernment and forethought in the employment of the axe cannot of course be looked for among the early colonists of a new country, but we have now reached a stage in our colonial career when it becomes absolutely necessary to set aside particular tracts of woodland for our future timber supply. ${ }^{64}$

60 Charles O'Neill, 7 October 1868, NZPD 14 (1868): 191-92, George P. Marsh, Man and Nature, or, Physical Geography as Modified by Human Action (New York: Charles Scribner, 1864), 279, 370, 512.

61 T. H. Potts, 7 October 1868, NZPD 14 (1868): 188.

62 Lyttelton Times, 26 January 1869, 23 February 1869.

63 Argus, 16 August 1867; Charles O'Neill, 7 October 1868, NZPD 14 (1868): 191.

64 Argus, 22 February 1868. 
This thinking was essentially the same as that which prompted Potts' motion in New Zealand eight months later. It provided both the precedent he needed and a blueprint for what might be done. In addition to the creation of plantations, the report recommended abolition of the existing system of timber licensing within state forest reserves. Commissioners, it said, should be appointed to enforce rigorous new regulations to 'prevent within such reserves the felling of trees under a certain size, ... compel the removal of the hewn timber within a reasonable time, ... [and] prevent the destruction of trees for sake of the bark only' ${ }^{65}$

When speaking in 1868, Potts made no reference to similar Otago proposals. It was left to two Otago MHRs, Donald Reid and Julius Vogel, to bring their province into the picture. Reid, in particular, recalled the narrow defeat of resolutions brought before the Otago Provincial Council earlier that year by William Mosley, which would have promoted the 'management and conservation' of 'public bush reserves' in Otago. ${ }^{66}$ Potts, in talking with his fellow MHRs in Wellington, would have learnt all about Mosley's and other initiatives. In particular, there are similarities between the forestry concerns of Potts in Canterbury and those of William Murison, MHR for Waikouaiti (in Otago) from 1866 to 1868.

In November 1867, Otago's government became aware of recent initiatives taken by the Board of Agriculture in Victoria. In response, they approached the officials of their province's agricultural societies (including Murison) for ideas on boards, model farms, and what 'new productions' might be encouraged. ${ }^{67}$ Murison, leaping at this opportunity to propose anything else of a 'similar nature', referred to the timber shortage in Otago and the need for tree-planting. He unfavourably compared his province's response to that of Canterbury, where 'neighbours vie with each other in promoting the art of sylviculture'. He also noted recent accounts of 'the improvidence of many European nations, in not replacing the forests which have been felled in time past'. For Otago, he suggested not only 'The preservation of the public bush reserves' but also that 'Land laid down in forest by private individuals might be exempted from taxation ... Reserves of land might be made for planting out ultimately in forest ... [and] land might be given on condition that it should be planted out with trees ${ }^{\prime}{ }^{68}$

One would think that calls for forest legislation in Otago, which paralleled and sometimes preceded those in Canterbury, might have influenced Potts' thinking at least as much as the Victorian proposals. Canterbury and Otago, after all, were neighbouring provinces, both with populations affected by the dearth of timber

65 Argus, 22 February 1868.

66 Roche, History of New Zealand Forestry, 67-68.

67 Otago Daily Times, 31 March 1868.

68 Otago Daily Times, 1 April 1868. Murison again pushed for 'the planting and conservation of forests' at an Otago Acclimatisation Society meeting in 1870: Otago Daily Times, 11 March 1870. 
to the east of the Southern Alps. In general, however, Victorian conservation efforts appear to have influenced Canterbury's and Otago's actions far more than the New Zealand provinces influenced each other.

There was one mention of the Canterbury Bush Fires Bill of 1863 in the Southland Times, but I have found none in Dunedin newspapers. In the following year, faced with their own fires, members of Otago's Provincial Council passed a Bush Fires Bill in May. This was noted in the Christchurch Press, but there is no indication that Otago was inspired by the Canterbury precedent. When Otago's provincial secretary introduced their bill, he unapologetically called it 'a copy of an Act existing in Victoria', minus certain clauses. ${ }^{69}$

\section{Response to Potts' motion}

Once the House of Representatives in Wellington had agreed to Potts' motion of 1868, Hector was instructed to gather information on 'the present condition of the forests'. As the head of New Zealand's Geological Survey and Director of the Colonial Museum, he was considered the best state employee for the job. Hector duly sent a questionnaire to provincial superintendents and their officials: [h] ow much forest was there in your area before settlement, he asked, and how much is left? How much remains as Crown land? Has most been destroyed on Crown land or on freehold, and how has it been destroyed? Is it being felled by the holders of bush licences, or is the destruction more by accidental fires and grazing cattle? Has the destruction of forests led to floods or droughts? Do you think bush reserves are a good thing, or is forest better conserved when it is freehold? If the system of bush licences leads to waste, how can forests be better managed so they provide timber but are not destroyed ${ }^{70}$ The responses, which were strikingly diverse, provide a panoramic view of opinions on native forests at the time. ${ }^{71}$

Take the question of bush reserves and bush licences. Cyrus Davie, the Chief Surveyor of Canterbury, thought 'bush licenses are not advisable ... They give men the right to go anywhere ... and to cut and destroy any quantity of timber. Having no permanent interest in the soil, they look only to the present, and often destroy as much valuable timber as they bring into the market' ${ }^{72}$ Southland's Commissioner of Crown Lands, Walter Pearson, however, thought the licensed

69 Southland Times, 27 October 1863; Otago Witness, 7 May 1864; The Press, 12 April 1864; Otago Daily Times, 12 April 1864.

70 Questions paraphrased from Appendices to the Journals of the House of Representatives (AJHR), D22, 1869, 3 .

71 AJHR, D22, 1869, 4-16.

72 'Correspondence Relative to the Present Condition of the Forests of New Zealand', AJHR, D22, 1869: 9. 
cutting of timber in government reserves could continue, but would need to be closely overseen by rangers if it was to promote conservation. Similarly Otago's Commissioner, John Turnbull Thomson, wanted government 'to appoint and pay Forest Wardens for the purpose of marking out the area to each licensee, no other area to be granted till the allotment is completely cleared of stems and branches'. It was 'the leaving of the branches', he said, 'that creates the great havoc during fires' ${ }^{73}$

Thomas Brunner, the Chief Surveyor of Nelson province, saw reserves in a different light. While reserves had originated from a desire (unfulfilled) to control the utilisation of their timber, he saw newer environmental arguments for them, prefiguring the 'climatic forest conservancy' proposed for New Zealand in 1877 by Inches Campbell Walker, and the 'climate reserves' introduced under Vogel's State Forests Act of $1885 .{ }^{74}$ Brunner thought the tops of many of the mountain ranges should be reserved on either side for a certain distance from their summit[s], and also that reserves should be made at the source of all rivers and streams'. Brunner envisioned what he called 'actual reserves', in which no timber would be cut.

Davie had no such a vision. 'We have now brought the fire into these forests', he wrote, 'and I believe it will be utterly impossible to preserve the remaining forests for any length of time'. He was certain that 'forests should be allowed to pass into freehold, as the only chance of their ultimate preservation'. Davie lived in an area already largely denuded of native forest and, like many Canterbury men, could see little future for what was left. Yet it was perhaps precisely because the timber shortage was so evident in their province, and the area of remaining forest so clearly finite, that a handful of Cantabrians (notably Potts and, by the 1890s, Leonard Cockayne and Henry Ell) were so alert to the need for its protection. ${ }^{75}$

Potts must have been encouraged when both the parliamentary debate of 1868 and the resulting questionnaire elicited several expressions of concern in line with his own. There were, however, no further parliamentary outcomes during his last year in the House of Representatives. At one point, while reminding the House that he 'had seen the whole [of Banks] Peninsula covered with one mass

73 Paul Star, 'T. H. Potts and the Origins of Conservation in New Zealand (1850-1890)' (M.A. diss., University of Otago, 1991), 77.

74 Roche, History of New Zealand Forestry, 91, 94.

75 Catherine Knight, 'Creating a Pastoral World through Fire: Manawatu, 1870-1910', Journal of New Zealand Studies, n. s., 16 (2013): 100-22, suggests that the regions most supportive of conservation had fewer forests, plus a greater number of 'wealthier immigrants from more highly educated backgrounds' (page 116) able to appreciate and promote conservation. Canterbury, and Potts, fit the bill. 
of smoke', he bemoaned the lack of progress since the publication of Hector's report. He feared there were now 'only two places in that locality [i. e. Banks Peninsula] where there was timber left that was worth preserving' ${ }^{\prime}{ }^{76}$

After 1870, Potts could no longer directly push for parliamentary action, though $\mathrm{O}^{\prime}$ Neill, now MHR for Thames (another gold-fields seat), remained in the House and maintained the pressure for conservation until upstaged by Vogel. ${ }^{77}$ National legislation in support of forest conservation finally resulted in 1874, six years after Potts' motion. ${ }^{78}$

In addition to the remarks already quoted, Davie also opined that 'legislation should lead rather to the encouragement of the new plantations than to the very doubtful attempt to preserve the old forests'. In the history of New Zealand conservation, Potts' motion is highlighted and approved; at the same time, the scepticism expressed by men like Davie is either ignored or condemned. But Potts himself increasingly doubted the effectiveness of any legislative cures. By the 1870s, his response to timber shortage no longer centred on political actions to save native forests. He still valued the forest, but he focused more on the potential for exotic tree-planting - as already stressed by Davie, among others.

By the end of the 1860s, three ways to promote tree-planting had been expressed. Firstly, legislation might encourage private individuals to plant trees. Secondly, government could organise the distribution of seeds and seedlings suitable for planting, primarily, by private individuals. Thirdly, government could take the bull by the horns and plant trees in its own 'public plantations'.

Looking mostly at the Canterbury picture in which Potts most persistently figured, I further differentiate two criss-crossing trails: one series of actions directly promoted legislation to encourage tree-planting, but there was also a wider-ranging push to support the colonial economy through development of 'local manufactures'. To Potts' way of thinking, conserved native forest and planted exotics would both foster future industry.

\footnotetext{
76 T. H. Potts, NZPD, 15 July 1870, 472.

77 Stephen Utick, Captain Charles, Engineer of Charity: The Remarkable Life of Charles Gordon O'Neill (Sydney: Allen and Unwin, 2008), contains little about O'Neill's support of forest conservation.

78 For details of O'Neill's unsuccessful efforts in 1872 and 1873, the withdrawal of Donald McLean's Conservation of Forests bill in 1873, and the successful passage of a modified New Zealand Forests Act (introduced by Vogel) in 1874, see Roche, Forest Policy in New Zealand, 73-80, and Roche, History of New Zealand Forestry, 83-88.
} 


\section{Local industry}

In order to develop, nineteenth-century New Zealand required both local industry and overseas income. By increasing the availability of resources and locally manufactured goods within the colony, the need to import essential items (such as building timber and furniture) was reduced. In addition, if a surplus of resources or goods could be exported overseas, this would provide income for colonials to import those essentials and luxuries, such as railway engines and cotton goods, which there was little or no prospect of producing locally.

As noted, Canterbury never had enough native forest to countenance the largescale export of native timber. In the 1850s, the province's ability to purchase depended on the merino wool clip. Potts, like the majority of MPCs, was a runholder and sheep-farmer. It was economically unhealthy, however, for a colony to have all its eggs in one basket. The situation was relieved by the discovery of gold in 1864 on the South Island's West Coast (then still part of Canterbury), but workable gold was a finite resource, and thoughtful settlers sought longer term sources of income.

Various ways forward were imaginable. Indigenous primary products with export potential, if plentiful, could be exported in a raw or semi-processed state. Or both indigenous and exotic species might become raw materials for colonial industries, producing processed goods. Such goods would certainly reduce the need for, and expense of, imports from Britain; in time they might also become export items. Or again, experimentation with introduced stock and plants could produce further raw materials for the British market, in addition to the existing export of wool.

By the early years of the twentieth century it had become clear that sheep (by then the source of both wool and meat exports) would continue to be the mainstay of Canterbury's economy, as for New Zealand as a whole. For settlers in the 1860s, however, there could be no certainty about how exports would develop, nor what new mineral resources might be found, nor when the population would grow large enough to support local industries by providing labour and increasing local demand. The only certainty was the wisdom of exploring all options.

Potts supported all these approaches. His interest in trees - which, in one form or other, could boost both overseas income and local industry-operated within his wider concern for the colony's development and its future health. To nineteenth-century New Zealanders in general, the native species with most export potential was harakeke (Phormium tenax). The very name used by European settlers for this plant - flax-emphasised the value of its fibre as a raw material, for in Britain, this word traditionally referred to the northern 
plant (Linum usitatissimum) from which linen was manufactured. As noted in 1823, however, 'the native [New Zealand] flax-plant ... is by no means like the flax or hemp plants of England'.$^{79}$ Already by the 1830s, New Zealand flax was being processed in London and promoted as the best resource for making sails and ropes for the British navy: it would see 'Neptune new rigg'd'. ${ }^{80}$ By 1868, one of the many flax-dressing businesses was located at Halswell on the edge of Christchurch, employing 'forty men and boys constantly' ${ }^{81}$

Potts in 1869 considered that if the spirited endeavour ... to establish a new export in the article of dressed flax, meets with success, we may expect very considerable attention will be paid to developing this new industry'. Since this meant 'most of the wild flax that is easily accessible will soon be used up', he looked forward to plantations of flax. Potts suggested that Canterbury's provincial gardener, John Armstrong, undertake 'experiments in the culture of flax ... showing how to obtain the best quality of fibre, the proper time and age for cutting, probable yield, \&c. ${ }^{82}$ - and this proposal was acted on. ${ }^{83}$ In 1870 , when the government set up a Flax Commission under the ubiquitous Hector, Potts became its Canterbury representative.

When Potts thought about the flax or any other industry, his mind often also turned to wood. Thus, immediately after describing flax's potential to the Canterbury Provincial Council in 1869, Potts also thought that, through Armstrong, 'sample logs of the furniture woods of the province might be collected and forwarded to the English agent, with particulars of the average obtainable size of such timber, as would be likely to be appreciated by manufacturers of ornamental furniture'. He considered, further, that 'the forests would furnish bark for dyeing and tanning purposes, the lichens covering the trees might in all probability possess dyeing qualities[;] resinous gums exuded from the Dammara and Panax, and ... vegetable oil had been expressed from titoki [Alectryon excelsus]'. ${ }^{84}$

All these local manufactures would have utilised native resources, but by the 1850s Britain's imperial record included numerous examples of species with resource potential which had been shifted not only from Britain to the colonies, but also between colonies. Thoughts, therefore, did not focus on what grew naturally in New Zealand so much as on what else might grow there. Sericulture

\footnotetext{
79 W. Ellis, Polynesian Researches ... in the South Sea Islands, vol. 1 (London: Fisher, Son \& Jackson, 1829), 27.

80 M. J. J. Donlan, Phormium Tenax, or Neptune New Rigg'd: Statement of Facts Relative to Experiments Made upon Phormium tenax or New Zealand Flax (London: W. Glindon, 1833).

81 J. S. Williams in Canterbury Provincial Council, 2 December 1868, as reported in Lyttelton Times, 3 December 1868.

82 T. H. Potts, 'Flax Culture', letter to the editor, Lyttelton Times, 8 February 1869.

83 Lyttelton Times, 18 February 1869.

84 T. H. Potts, 7 October 1868, NZPD 14 (1868): 188
} 
(the raising of silkworms for the production of raw silk) was perhaps the first exotic industry to which Potts gave thought. In 1853, the year before he left England for New Zealand, he sent ahead a Wardian case of white mulberry seedlings, their leaves being the food that silkworms eat. These were planted on Potts' behalf in Lyttelton. ${ }^{85}$ Two years later, Potts transplanted them to his garden at Valehead, near Rockwood. ${ }^{86} \mathrm{~A}$ decade later still, the Canterbury Acclimatisation Society received silk worms from Sydney and distributed them among interested members such as himself. ${ }^{87}$

Sugar beet and cloth production, like sericulture, became perennial candidates for local industries for both the New Zealand and Australian colonies. As an MPC in December 1868, Potts successfully moved that 'the Government be requested to offer premiums for tweed cloths, blankets, and beetroot sugar manufactured within the province' ${ }^{88}$ This time Potts noted not only a successful Victorian cloth industry, but also the Otago Provincial Council's recent offer of premiums for local cloth and sugar beet production. ${ }^{89}$ He had himself just received a package of tweeds (presumably locally produced) from Nelson. ${ }^{90}$

\section{Private tree-planting}

A national initiative followed in 1870 when a parliamentary joint committee, which included Potts, $\mathrm{O}^{\prime} \mathrm{Neill}$, and Travers among its members, spent a few days in July gathering ideas on possible 'colonial industries'. In the resulting report, the first six recommendations all related to the exploitation of New Zealand's mineral resources, drawing on information from their star witness: Hector.

There was also, however, a recommendation that 'persons planting timber trees upon unsold Crown lands should ... be secured in the freehold of the country so planted out, either by pre-emptive right of purchase or by free gift' ${ }^{91}$ This would have given government a role in encouraging tree-planting, but no direct involvement. In this respect, it matched other recommendations in the report with regard to sericulture and sugar beet, and for free passage to New Zealand for Welshmen and Yorkshiremen versed in cloth manufacture.

\footnotetext{
85 The Press, 18 June 1870.

86 T. H. Potts, Diary, 17 September 1855.

87 Star, 18 June 1870.

88 Lyttelton Times, 3 December 1868.

89 The Press, 3 December 1868. Six months later Canterbury's government had also advertised premiums, but no other action followed. The Press, 21 May 1869.

90 'Shipping', Lyttelton Times, 11 November 1868.

91 'Report of the Joint Committee on Colonial Industries', AJHR, F-1 (1870).
} 
Years earlier, in 1856, John Hall had promoted private plantation at the provincial level..$^{92}$ This precipitated the Planting of Forest Trees Ordinance of 1858, 'to encourage and promote the planting of Forest Trees on Rural Sections in the Province of Canterbury'. The ordinance sought to ensure that, if a tenant planted more than 50 timber trees on a 10-acre (4.05 hectare) or larger section, he could cut them down or transplant them prior to the expiry of his lease, or else arrange for their mandatory purchase at an agreed price by his landlord. ${ }^{93}$

This was a removal of obstacles more than the provision of incentives. Given proper registration, Hall thought tenants would no longer feel discouraged from proceeding with plantations. Whether this had any tangible result is unknown, but clearly it was not enough. Five years later, in 1863, an anonymous correspondent of the Lyttelton Times still found that 'want of timber is the greatest of all our necessities, and one not likely to be mitigated for a considerable time' ${ }^{94}$ Nevertheless, no further legislation to encourage planting, other than the development of Hagley Park in central Christchurch, was passed by the Council in the 1860s.

One attempt was made, however, during a Council meeting in October 1869 at which Potts was present. On this occasion, John Evans 'Yankee' Brown, MPC, proposed tree-planting encouragement policies along American lines. He thought there should be a 10 per cent discount on the rates for every acre of land planted and protected. His motion was withdrawn at the request of Hall, who I suspect already had a new proposal in mind and did not want Brown muddying the waters. ${ }^{95}$

Hall proved to be a more consistent and persuasive politician than Brown or Potts ever was. In 1871, he introduced a Canterbury Forest Trees Bill in the House of Representatives in Wellington. It transmogrified into the Forest Trees Planting Encouragement Act of the same year, which granted two acres of free land to any settler who had planted one acre of their land in forest trees. Thus, Hall's dogged support of private plantation - promoted at the provincial and national level, and on his own sheep station - eventually ensured that this approach received a significant trial through the 1870s and 1880s. ${ }^{96}$ Furthermore, South Australia's Tree Planting Encouragement Act of 1873 was directly modelled on the New Zealand precedent, illustrating that not all innovative policies crossed the Tasman Sea in an easterly direction. ${ }^{97}$

92 Lyttelton Times, 26 April 1856.

93 The Ordinances of the Canterbury Provincial Council Session 10, October to December 1858.

94 Lyttelton Times, 3 June 1863.

95 The Press, 21 October 1869.

96 For further detail, see Star, 'Tree Planting in Canterbury'.

97 Beattie, Empire and Environmental Anxiety, 166-67. 
In the event, Hall's measure proved inadequate to stimulate the volume of timber production required in New Zealand's rapidly expanding economy. That left the way clear for more direct government involvement in forestry, including state planting, as legislated for by Vogel in 1874. I note here only that, while Vogel's support of forestry development from 1873 onwards is well known, little attention has been given by historians to the earlier efforts made by Hall (a later Premier) and to the approach he pioneered..$^{98}$

\section{Organising supply}

Potts did not personally take advantage of the terms of the tree-planting encouragement acts: He was planting trees anyway. He had fruit trees growing in Valehead before his move to Governor's Bay in 1858; by 1863 his cherry crabs were prize-winners at the Christchurch Horticultural Show and a string of such prizes followed. ${ }^{99}$ These were fruit-growing and horticultural endeavours, but he was equally involved in all aspects of silviculture, including tree-planting.

Potts disputed popular beliefs that native trees were hard to transplant or establish outside forest conditions, but he agreed that in general they were too slow-growing to be suitable for timber plantations. This is not to say that he had no interest in growing them: indeed, in September 1870 he spoke 'on the cultivation of some species of native trees and shrubs' to the Wellington Philosophical Society, summarising what he and his gardener had learned 'from the experience of several years' ${ }^{100}$ But it was almost a given at the time that treeplanting initiatives would relate to the planting of exotics, not natives.

There was a sequential enthusiasm for different exotic species during the $1850 \mathrm{~s}$ and 1860s, which Potts himself recorded:

Of necessity willows and poplars, a case of Hobson's choice, were the first loves of the tree-growers ... They soon had their day, as a few seedling gum trees

98 The biographies of both men deal only briefly with their tree-planting and forestry interests. See Jean Garner, By His Own Merits: Sir John Hall-Pioneer, Pastoralist and Premier (Hororata: Dryden Press, 1995), 67-68 and 128-29, and Raewyn Dalziel, Julius Vogel: Business Politician (Auckland: Auckland University Press, 1986).

99 Lyttelton Times, 4 March 1863.

100 T. H. Potts and William Gray, 'On the Cultivation of Some Species of Native Trees and Shrubs', Transactions of the New Zealand Institute 3 (1870): 181-202. They noted (page 181) 'a prejudice against planting native shrubs, from the supposed difficulty attending their successful treatment'. Most early settlers accepted, as Darwinian scientists of the day theorised, that the displacement of native trees by (supposedly) superior 'northern' species was inevitable. Dr Arthur Purchas gave a classic expression of this view before the Auckland Institute in 1874: '[s]ome of the New Zealand trees might be preserved, but many of them could not resist the advances of civilization, and, like the native birds, would in time almost entirely vanish. It was a natural result, and they must not bemoan it, but rather make preparations for filling their place with trees that would live and bear cultivation'. Proceedings of the New Zealand Institute 7 (1874): 519-20. 
showed such extraordinary vigour and rapidity of growth that they induced a fashion to sow seeds of Australian trees ... The desire of cultivating Australian species in turn gave way before the furore for growing Californian conifers[.] ${ }^{101}$

Potts planted Australian blue gum (Eucalyptus globulus) at Governor's Bay in the late 1850s, but by July 1865 his attention had turned to Pinus ponderosa, from western North America. ${ }^{102}$

In 1866, Potts launched into a diverse tree-planting programme, mostly involving pines (he had 18 different species of these by 1870), but also cedars and cypresses. He regularly assessed their growth, tabulating and publishing results until 1885, by which time he had conclusively shown that, under local conditions, Monterey pine (now known as Pinus radiata) grew the fastest. ${ }^{103}$ This was a conscious and conscientious attempt to ascertain which trees held greatest potential for future timber supply in Canterbury.

Potts was also associated with tree-planting ventures in Christchurch's domain (which became its botanic garden) and neighbouring Hagley Park, which were government-funded activities on public land. The origins of the Hagley Park plantings can be traced back to 1858 when Richard Harman MPC, at a Council meeting attended by Potts, had $£ 200$ set aside to plant out a portion of the Park. Harman opined that private planting was insufficient, 'considering that one of the special and most objectionable features of the country was want of timber'. ${ }^{104}$ The development of the Park that followed, however, was pursued more for its amenity value.

Operations in the Park at this time should not be underestimated. By 1864, the nursery of Enoch Barker, the provincial government gardener, was four acres (1.6 hectares) in extent:

From this nursery the whole of the domain, which comprises about fifty-nine acres [24 ha], is supplied with the young stock planted in the latter. In one bed are five thousand varieties of native shrubs and trees. In another are layers of birch and lime ... Ten thousand oak plants, one thousand Spanish chestnuts, and a very large number of elms, box, and laurels are planted here, and in due time will be removed to their destined place in the public plantation. Twentyfive thousand young plants have already been placed there, forty thousand remaining in the nursery. ${ }^{105}$

101 T. H. Potts, 'Old Times', Canterbury Times, 2 December 1887, 28; 9 December 1887, 28.

102 Potts, Diary, 15 May 1865 and 6 July 1865.

103 See T. H. Potts, 'Through a Young Plantation', New Zealand Country Journal 2 (1878): 390-97 and 3 (1879): 34-38; T. H. Potts, 'Measurements of Some Coniferous Trees Planted in 1866 in Ohinitahi, Canterbury', New Zealand Country Journal 9 (1885): 477

104 Lyttelton Times, 6 November 1858

105 Lyttelton Times, 15 October 1864. See also 'Citizen' on 'Government Plantations' in Lyttelton Times, 19 April 1864, 18 April 1860, and 16 November 1861. 
In 1864 , the annual vote was $£ 1,196$ for 'public plantation' ${ }^{106}$ The Provincial Council provided similar annual sums for public plantations on either side of 1869, when Potts commented on how such operations could be refocused and extended. Planting therefore continued without reflection on how it might have addressed Canterbury's timber shortage. Opposing the public plantation vote in 1871, a member of the new city council argued that 'there were a number of streets wanting forming and repairs, and he thought it was far better to have useful works carried out in preference to ornamentation' ${ }^{107}$

Public planting in Christchurch, at least of this kind, was well ahead of anything in Wellington, but the situation in New Zealand's capital city was reformed by the Botanic Garden of Wellington Act of September 1869. Canterbury MHRs Potts and Travers were among those who spoke up for the Act, which paved the way for Hector (as its Director) to make the garden serve New Zealand's forestry needs. Hector had recently received a collection of the seeds of 200 species from the Royal Botanic Gardens at Kew in London, and now he had somewhere to propagate them. Thereafter, Wellington's botanic garden became the centre of a network of tree-planting endeavours that operated throughout the colony. ${ }^{108}$

This network built upon the more ad hoc exchange of seeds and seedlings, largely between private individuals, which already existed. In 1868, for instance, Edward Richardson of Albury Park in Canterbury wrote to Professor Martin Kellogg of San Francisco for some Pinus radiata seed, which I suspect was the source of some of the radiata seedlings that Potts planted. Certainly Potts was the middleman in 1871 when he arranged for the transfer of seedlings from Richardson in Albury to Hector in Wellington; and in due course Kellogg became the principal supplier of Californian conifer seed to the New Zealand government. ${ }^{109}$

In 1870, while answering the Committee on Colonial Industries' questions about gold, coal, and sericulture, Hector also addressed the subject of timber supply. $\mathrm{O}^{\prime}$ Neill asked him if steps should be taken 'for the conservation of the existing forests' and he replied (as $\mathrm{O}^{\prime}$ Neill or Potts themselves would have) that 'the rapid destruction of the native forests I consider to be most wasteful, and as having the effect of rapidly reducing the natural resources of the country'. ${ }^{110}$

106 The Press, 14 September 1864. A similar amount went to the Acclimatisation Society to introduce exotic birds and fish.

107 The Press, 4 April 1871.

108 Winsome Shepherd and Walter Cook, The Botanic Garden, Wellington: A New Zealand History, 1840-1987 (Wellington: Millwood Press, 1988), 25.

109 Shepherd and Cook, The Botanic Garden, Wellington, 123-24.

110 'Report of the Joint Committee on Colonial Industries', AJHR (1870) Session I, F-1, 10. 
His principal line, however, was that the subject of the immediate planting of large portions of the Colony, from which the natural forest has been denuded, with the most profitable class of introduced trees is one of the most important in this Colony'. His emphasis lay not with 'land laws encouragement', nor with some new kind of public plantation such as Potts had proposed a few months earlier. Rather, Hector wanted the government to 'provide machinery for the distribution at a moderate price of the best varieties of trees'. These would be 'raised from seed on a large scale, and distributed when they have reached the proper time for transplanting'. The committee's recommendations did not reflect this piece of advice from Hector, but his comments referred to a procedure upon which, as we have seen, he had already spent government funds. ${ }^{11}$

\section{Public plantations}

Potts wanted government action to go further. Just as he envisaged flax plantations supplementing naturally growing flax, so Potts saw a need for timber trees grown in plantations to supplement the timber supply from native forests. With trees, as with flax, he felt that government should play its part through research and education, and provision of incentives and publicity. In the case of trees, however, Potts went significantly beyond most his contemporaries in the 1860s, in arguing that government should not only encourage individual landowners to plant them, but also should itself plant trees.

Potts first wrote to the Lyttelton Times about plantations in January 1869, a month before his letter on 'flax culture'. His January letter, headed 'local manufactures', similarly combined discussion of 'two important matters, affecting the good of the province'. Firstly, he sought to hurry along the provincial government's initiation of local manufactures. ${ }^{112}$ Secondly, Potts mooted his idea of public plantations, planted with timber trees to replace those destroyed in bush fires. Having opposed the issuing of timber cutting licences as wasteful, he welcomed the decision to issue no more. But he wanted government to

go a step further and devote a certain proportion of the amount realised from the sale of timber land for the purpose of public plantations. We yearly devote a sum of money for public plantations for the ornamentation of the chief town of the province. Let us take into consideration use, as well as ornament, and extend our operations. There are many localities where extensive plantations would provide a great climatic benefit, and it does not require any very long journey across the plains of Canterbury to appreciate the value of this provision for the future supply of valuable timber.

111 Shepherd and Cook, The Botanic Garden, Wellington, 95-98.

112 Lyttelton Times, 26 January 1869. 
As when putting his ideas on forest conservation to the House of Representatives a few months earlier, he recommended the Victorian government's forestry report for further information on the subject.

Potts acknowledged that public plantations already existed, in the form of the ornamental trees planted in Hagley Park and elsewhere. But what he was now suggesting was quite different, as he explained in a further letter to the Lyttelton Times. ${ }^{113} \mathrm{He}$ envisaged not only 'special reserves for plantations of useful forest timber', but also 'planting on portions of the reserves that are at present set aside for educational and other public purposes'.

He pointed out that public plantations would help Canterbury's balance of payments, given that 'the wood of various kinds we have imported must during several years have amounted to a very large annual outgoing'. He then adopted a more moral tone: through planting trees, he said, we acted as 'faithful stewards, looking to the future well-being of the community'. He envisaged gains not only in terms of timber supply but also in terms of climate. ${ }^{114}$ As Peter Holland points out, flooding was a major concern of Canterbury residents in the 1860 s. ${ }^{115}$

Potts further suggested that osier willows planted in 'marshy swamp' would supply 'material for basket-ware, hoops, etc, its bark furnishing a good proportion of tannin, as well as enabling our chemists to extract from it the crystallisable principle salicin, which like the sulphate of quinine, arrests the progress of fever'. He had earlier stressed the potential value of native trees for furniture-making. Now he was saying that exotic trees in public plantations might stimulate other industries.

In the context of New Zealand in 1869, Potts' call for this new kind of public plantation was quite radical. Consider the response it elicited from a longstanding friend, Mark Stoddart. He similarly wanted

plantations to supply [i. e. make up for] the waste and destruction that has been going on in the natural forests of our province, and, likewise, with a view to ameliorate the rather hard and shelterless features of our climate. I fully concur with him [Potts] in the necessity that something should be done in that direction.

113 Lyttelton Times, 23 February 1869.

114 Potts enlarged upon the idea of 'climatic benefits' by quoting directly from the Victorian report: forest trees changed the climate 'by modifying extremes of temperature, and increasing the humidity of air, by causing a more continuous rainfall in districts that are now subject to long and excessive droughts ... The vegetable mould formed by the decomposition of leaves and wood not only enriches the surface soil, but causes it to become much more absorbent, and, from its spongy nature, to retain a large portion of the rainfall that would otherwise drain away by percolation at great depths, or flow off rapidly by surface channels. It is chiefly due to this last that in dense forests heavy rains do not cause such violent floods as in open country'. Lyttelton Times, 23 February 1869.

115 Peter Holland, Home in the Howling Wilderness: Settlers and the Environment in Southern New Zealand (Auckland: Auckland University Press, 2013), 71-75. 
But, before going into the subject of public plantations - which is surrounded with many practical drawbacks and difficulties, besides the important one of expense-I would, with all diffidence, make a few suggestions as to planting, and urge them upon freehold proprietors, with whom the planting movement should begin. ${ }^{116}$

The idea of public plantations was ideologically challenging: it went against early Victorian preferences, still strongly held in 1869, for a laissez-faire approach, private enterprise wherever possible, and minimal government. A leader in the Otago Daily Times three months later agreed that 'wise and liberal legislation might greatly promote ... the planting of timber trees'; however, it was 'no part of the proper business of the Government to undertake such work itself' ${ }^{117}$ Public plantations were no more than a pipe dream at the time, whereas private plantations were already being created by Potts and dozens of other landowners.

\section{Discussion}

The situation changed after 1870, as population increased and colonial development accelerated. The limitations of policies encouraging private tree-planting (and towards other forms of private enterprise) became evident. Private tree-planting and its promotion characterised early efforts to involve government in the forest question; by the end of the century, however, public plantation (along with native forest conservation) had become a key feature of the government's forest policy. ${ }^{118}$

Looking at New Zealand in the 1860s and into the 1870s, I also find good cause to stress local concerns and the tree-planting response. And certainly, among those who claimed a reward under the Tree Planting Encouragement Acts were many men who (unlike Potts) never showed a parallel interest in native forests or their conservation. But there is perhaps a need to better differentiate between the origins of forestry concerns on the one hand, and the structuring of legislative responses on the other. The former began at the local level and resulted mostly in tree-planting in the first instance. The latter developed later, and drew not only on local realities but also on European precedents, sometimes through an Indian filter. In the case of New Zealand, there was often also an Australian filter, since Victoria in particular had already begun the adaptation of European

116 Lyttelton Times, 2 March 1869.

117 Review of Transactions of the New Zealand Institute, vol. 1, in Otago Daily Times, 13 July 1869.

118 Paul Star, 'Henry Matthews' Contribution to Tree Culture in New Zealand from 1896 to 1909 ', in Australia's Ever-Changing Forests, vol. 6, Proceedings of the Eighth National Conference on Australian Forest History, ed. Brett J. Stubbs, Jane Lennon, Alison Specht, and John Taylor (Canberra: Australian Forest History Society, 2012), 201-24. 
ideas to colonial contexts. Potts, in the 1860s, was one of the first to bring this range of responses to bear on the local situation in Canterbury and elsewhere in New Zealand.

The historical study of New Zealand's forest legislation remains patchy and is still dominated by Michael Roche's research, done over 30 years ago. ${ }^{119}$ More recently, James Beattie has placed the New Zealand evidence within a broader, and primarily British imperial, context, though with German influences as an aside. ${ }^{120}$ The present paper, by looking exclusively at forestry concerns in the 1860s, and especially at those of Potts in Canterbury, has concentrated on one small part of this overall picture. A couple of absences are worth mentioning.

Absent, firstly, has been the suggestion for New Zealand to have a Board of Woods and Forests and a Conservator of Forests, as was put forward by William Lauder Lindsay after his visit to Otago of $1861-62 .{ }^{121}$ This has not been mentioned because I have found no evidence that Potts had heard of the man or his writings. Even in Otago, there seems to have been little awareness or interest in Lindsay's forestry proposals during the nineteenth century. I have referred to Otago Provincial Council discussions on bush reserves of 1868, for Potts and others outside Otago knew of these. But I believe that Canterbury and Otago responses at this time, rather than being symbiotic, were independently derived from Victorian developments.

Absent, secondly, is any mention of forestry practices in British India. There were certainly old India hands in New Zealand in the 1860s with knowledge of the Indian forest service. Beattie has instanced two Canterbury men: John Cracroft Wilson, who arrived at Lyttelton two weeks before Potts in 1854, and De Renzie James Brett, who arrived in 1865. ${ }^{122}$ 'Nabob' Wilson served with Potts both as an MPC and an MHR and shared many interests with him, but, for all that, there is nothing in Potts' remarks suggesting he had much awareness of Indian forestry, or that it influenced his thought in the 1860s. I do, however, refer to the influence on Potts and others of George Perkins Marsh.

Environmental historians debate whether the origins of conservation are more meaningfully traced back to the influence of Man and Nature or (as Richard Grove would have it) to the concerns of imperial servants in India and elsewhere

119 Presented, most notably, in Roche, History of New Zealand Forestry.

120 Beattie, Empire and Environmental Anxiety, 143-48.

121 W. L. Lindsay, The Place and Power of Natural History in Colonization, with Special Reference to Otago (Dunedin: YMCA, 1862); W. L. Lindsay, 'On the Conservation of Forests in New Zealand', Journal of Botany British and Foreign 6 (1868): 38-46. See also James Beattie, 'Scottish Environmentalism and the "Improvement" of Nineteenth-Century New Zealand', in Landscape/Community: Perspectives from New Zealand, ed. Tony Ballantyne and Judith A. Bennett (Dunedin: University of Otago Press, 2005), 43-56.

122 See James Beattie, 'Making Home, Making Identity: Asian Garden Making in New Zealand, 1850s-1930s', Studies in the History of Gardens and Designed Landscapes 31, no. 2 (2011): 139-59. 
in the British Empire. ${ }^{123}$ My research confirms the influence of Marsh in New Zealand by the 1860s, but it was only in the 1870s (and then powerfully so) that Indian practice began to affect the country's forest legislation and its ideas of conservation.

Graeme Wynn, whom I referred to in my introduction, published a second article on New Zealand forest history in 1979. As with his first article, this concentrated on the New Zealand Forest Act of 1874, but it also looked a little harder at precedent events and at settlers like Potts, Travers, and O'Neill. 'Through the work of this well-informed and essentially conservative minority in the pioneering population of the colony', Wynn wrote, 'ideas emerging from the experience of environmental exploitation and ecological disturbance elsewhere were superimposed upon the primal encounter between man and the land in New Zealand'. ${ }^{124}$ In a third article by Wynn, published 25 years later, he wondered if his early work had overstressed the role of Man and Nature in informing these settlers, when in fact 'New Zealanders might have built their understanding, at least in part, on grounds other than Marsh'. ${ }^{125}$

By closer tracking of the situation in Canterbury in the 1860s, we can now better see precisely what was superimposed on what, and the order in which this occurred. In my analysis, Victorian legislation and Marsh's book were the key external influences that structured the concern about forests and conservation that Potts, most notably, felt. ${ }^{126}$ They provided the syntax, but the substance was a local response to ongoing change in a local environment. What Potts and others expressed in the 1860s was based in the first instance upon what they themselves experienced: that is, upon forest and fire, waste and shortage, development and opportunity.

Looked at this way, it is not incorrect to view Potts' motion of 1868 and his views at the time on native forest conservation as proto-environmentalism. It can, however, be restricting. What I have wanted to show through a case study

123 Richard Grove, Green Imperialism: Colonial Expansion, Tropical Island Edens and the Origins of Environmentalism, 1600-1860 (Cambridge: Cambridge University Press, 1995).

124 Graeme Wynn, 'Pioneers, Politicians and the Conservation of Forests in Early New Zealand', Journal of Historical Geography 5, no. 2 (1979): 187.

125 Graeme Wynn, “'On Heroes, Hero-Worship, and the Heroic” in Environmental History', Environment and History 10 (2004): 144.

126 The other overseas influences noted in 2004 by Wynn relate to the 1870s, several years after the impact of Marsh's work in New Zealand had begun. In my assessment, they strengthened Marsh's case, but they were taken on board later and were, essentially, supplementary evidence to that which Marsh had already provided. Nelson engineer Arthur Dobson's article 'On the Destruction of Shingle-Bearing Rivers', Transactions of the New Zealand Institute 4 (1871): 153-57, as Wynn indicated in 2004, fuses Marsh's ideas, Dobson's own experience and 'local understanding of the processes involved', as already interpreted by 'his German-trained brother-in-law, geologist and explorer Julius von Haast'. The Dobson, Haast, and Potts families were very close - Arthur Dobson's brothers later married two of Potts' daughters - and no doubt they shared insights about the local environment gained both from their own observation and by the application of ideas culled from what they read. 
of Canterbury province is that, at least in the 1860s, concern for the native environment was primarily an aspect of concern for colonial development, and that conservation of native forests was primarily a counterpoint to exotic tree-planting. There are major differences between the priorities of nineteenthcentury actors and twenty-first-century analysts of their ideas and actions. Nineteenth-century perspectives need to be identified and understood before any selective plucking of evidence for the origins of modern conservation.

Fuller understanding of the complexity of concerns about the wastage of native forests in the 1860s may help us to situate New Zealand's present, and ongoing, ambivalence towards conservation and growth. Study of this particular decade is, more certainly, a necessary backdrop to the examination of changes later in the nineteenth century. The years between 1870 and 1900 witnessed not only the state's growing sense of responsibility for native forest conservation and exotic timber production, but also a distinct shift in settler responses to native forests. ${ }^{127} \mathrm{I}$ hope in a subsequent paper to show how, in the remaining two decades before his death in 1888, Potts' actions and writings continued to reflect, and contributed to, these changes. 
This text is taken from International Review of Environmental History, Volume 1, 2015, edited by James Beattie, published 2015 by ANU Press, The Australian National University, Canberra, Australia. 